\title{
Starch-iodine test: a diagnostic tool for Horner syndrome
}

\author{
Luís Ribeiro, ${ }^{1}$ Raquel Rocha (10, ${ }^{1,2}$ João Martins, ${ }^{1,3}$ Ana Monteiro ${ }^{1,4}$
}

\begin{abstract}
${ }^{1}$ Neurology Department, Hospital Pedro Hispano, Unidade Local de Saúde de Matosinhos, Matosinhos, Portugal

${ }^{2}$ Harvard Medical School, Boston, Massachusetts, USA

${ }^{3}$ Medicillisboa, Lisboa, Portugal ${ }^{4}$ Faculty of Medicine of University of Porto, Porto, Portugal
\end{abstract}

Correspondence to Dr Raquel Rocha; rmrocha84@gmail.com

Accepted 28 August 2020

\section{DESCRIPTION}

We present the case of a 62-year-old woman that reported right hemibody excessive sweating, which slowly progressed over 15 years, and which caused great social embarrassment. On examination, right hemibody hyperhidrosis was observed. A very slight anisocoria was also present (ambient light: right $3 \mathrm{~mm}$; left $2 \mathrm{~mm}$; light stimulation: right $2 \mathrm{~mm}$, left $1.5 \mathrm{~mm}$; dark: right: $5 \mathrm{~mm}$; left $2.5 \mathrm{~mm}$ ). The patient previously underwent bilateral blepharoplasty for excess palpebral skin, complicating evaluation of ptosis; however, a slight left ptosis was apparent. A Harlequin sign was not reported by the patient, nor noticed after exercise.

A starch-iodine test was performed, revealing left hemibody anhidrosis. To perform the starch-iodine test, we first thoroughly dried the patient's skin with a $70 \%$ alcohol solution, then applied an iodine solution and allowed the skin to dry completely. Next, we dusted the skin with a thin film of starch (corn flour) (figure 1). Finally, we encouraged sweating (hot room and exercise) and after $25 \mathrm{~min}$ we evaluated the results. The patient's right hemibody readily turned a dark blue shade when in contact with sweat, while the left side remained unchanged (figure 2).

An apraclonidine test was performed, causing left pupil dilatation. Cervico-thoracoabdominal-pelvic CT scan, neuraxis MRI, carotid doppler ultrasound and extensive laboratorial study were unremarkable. Based on these results, the diagnosis of idiopathic Horner syndrome was made. The patient was then administered oxybutynin (an anticholinergic drug) to reduce the excessive sweating on

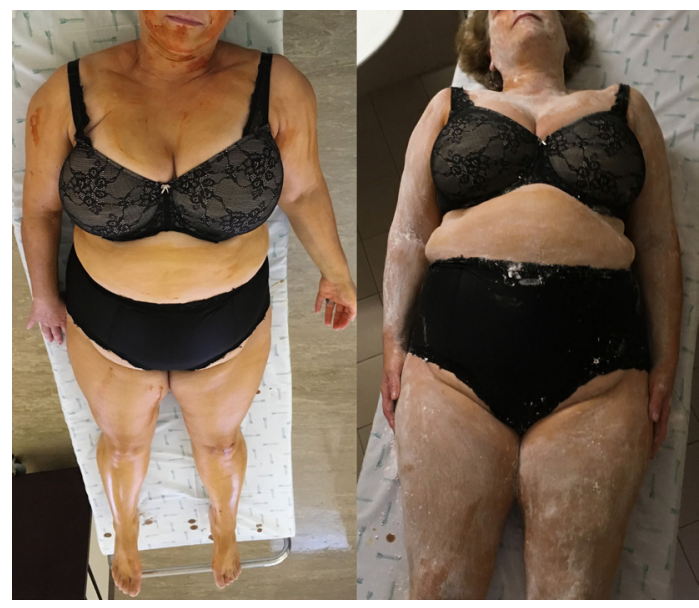

Figure 1 Thoroughly dry the skin with an alcohol solution. Then, apply an iodine solution and let it dry completely. Dust with a thin film of starch.

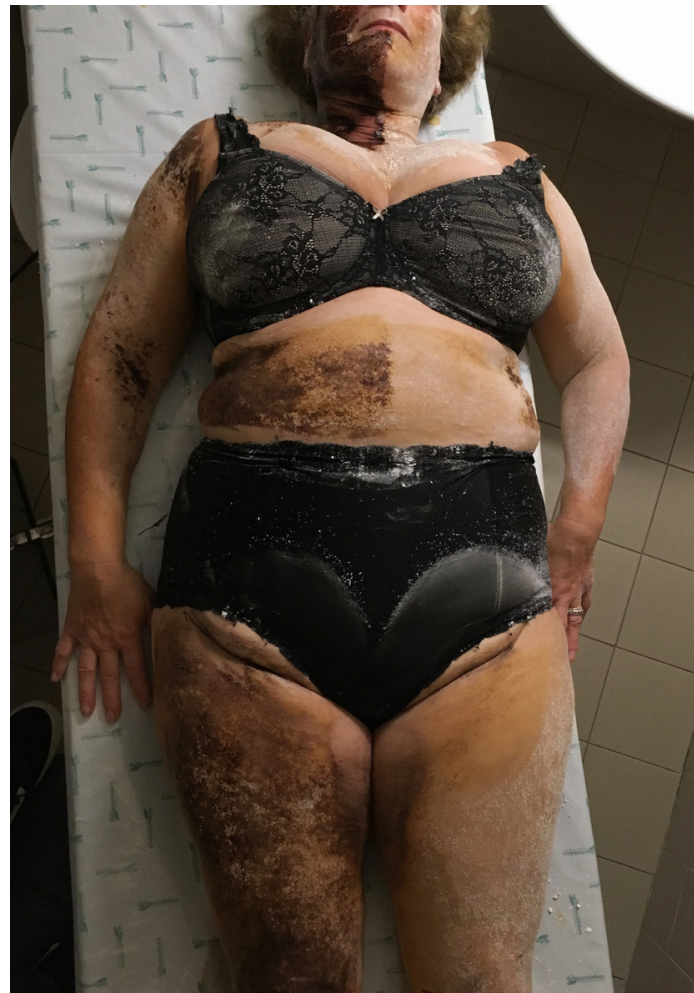

Figure 2 Encourage sweating (hot room, exercise): an unforgettable dark blue coloration develops on the normal hemibody, strictly respecting the midline, and thus demonstrating contralateral anhidrosis.

the contralateral hemibody, resulting in a greatly improved quality of life.

Currently, the starch-iodine test is rarely used in clinical practice. However, it is simple, inexpensive

Learning points

- Horner syndrome is clinically diagnosed when the patient presents decreased pupil size aggravated in scotopic conditions, ipsilateral drooping eyelid and decreased sweating on the affected side of the body.

- The starch-iodine test is a simple but powerful tool for the diagnosis of Horner syndrome. It is readily available, inexpensive and devoid of side effects.

-When positive, the normal hemibody acquires a dark blue or purple coloration, while the affected hemibody remains unchanged, thus confirming a lack of sweating on the affected side. 
and does not produce the common side effects associated with other tests used in this context (such as the cocaine or apraclonidine tests, quantitative sudomotor axon reflex and thermoregulatory sweat tests). Moreover, the starch-iodine test is readily available and easy to interpret, even for patients, provided they are told what to expect. ${ }^{12}$ In this case, the test demonstrated to the patient that the problem was in fact contralateral lack of sweating with compensatory excessive sweating on the right. Overall, the test aided immensely in clarifying the diagnosis.

For all of these reasons, we believe that the starch-iodine bedside test can be a very effective alternative for hospitals with few technical resources and/or where more specialised diagnostic testing isdifficult to obtain in a timely manner (an increasingly important consideration given the current pressures exerted on global health systems by the COVID-19 pandemic).

\section{Acknowledgements We thank Scott Lipkowitz and Christian Bright for} proofreading.
Contributors $L R$ and AM conceived the presented idea. LR and JM did the first draft. RR and AM supervised the findings of this work and help writing the final manuscript. All authors discussed and contributed to the final manuscript.

Funding The authors have not declared a specific grant for this research from any funding agency in the public, commercial or not-for-profit sectors.

Competing interests None declared.

Patient consent for publication Obtained.

Provenance and peer review Not commissioned; externally peer reviewed.

\section{ORCID iD}

Raquel Rocha http://orcid.org/0000-0001-8610-8925

\section{REFERENCES}

1 Guttmann L. The management of the quinizarin sweat test (Q.S.T.). Postgrad Med J 1947;23:353-66.

2 Sriraam LM, Sundaram R, Ramalingam R, et al. Minor's test: objective demonstration of Horner's syndrome. Indian J Otolaryngol Head Neck Surg 2015:67:190-2.

Copyright 2020 BMJ Publishing Group. All rights reserved. For permission to reuse any of this content visit

https://www.bmj.com/company/products-services/rights-and-licensing/permissions/

BMJ Case Report Fellows may re-use this article for personal use and teaching without any further permission.

Become a Fellow of BMJ Case Reports today and you can:

- Submit as many cases as you like

- Enjoy fast sympathetic peer review and rapid publication of accepted articles

- Access all the published articles

Re-use any of the published material for personal use and teaching without further permission

Customer Service

If you have any further queries about your subscription, please contact our customer services team on +44 (0) 2071111105 or via email at support@bmj.com.

Visit casereports.bmj.com for more articles like this and to become a Fellow 